\title{
Physiological and biochemical responses of sugarcane to oxidative stress induced by water deficit and paraquat
}

\author{
Claudiana Moura dos Santos ${ }^{1} \cdot$ Marcelo de Almeida Silva ${ }^{1}$
}

Received: 8 October 2014/Revised: 23 July 2015/ Accepted: 27 July 2015/Published online: 5 August 2015

(C) Franciszek Górski Institute of Plant Physiology, Polish Academy of Sciences, Kraków 2015

\begin{abstract}
Physiological and biochemical responses to oxidative stress induced by paraquat or water deficit were examined in this study with respect to photoinhibition, stomatal conductance, photosynthetic pigments, organic solutes, and antioxidant enzymes, aiming at a better understanding of the defense networks connected with antioxidant agents in sugarcane and also to identify cultivars more tolerant to such stress conditions. In the droughtinduced experiment, the plants were exposed to 15 days without irrigation, and in the study with paraquat (PQ), $150 \mu \mathrm{M}$ of the herbicide was applied to the plants $24 \mathrm{~h}$ before the evaluations, conducted simultaneously with the drought experiment. In the second part of the experiment leaf disks were cut from cultivars and immersed in a paraquat solution in Petri dishes and analyzed for chlorophyll degradation. In cultivars SP83-2847 and IAC915155 , smaller reductions were observed in the maximum photochemical efficiency of photosystem II $\left(F_{\mathrm{v}} / F_{\mathrm{m}}\right)$ and photosynthetic pigments, when submitted to water deficit and treated with paraquat, and greater reductions were found in cultivars RB92579 and SP81-3250 which had lower dry matter under drought stress. Paraquat produced a toxic effect because of degradation of proline and carbohydrates in cultivars. Both stressors led to an increase in the activity of superoxide dismutase (SOD), catalase
\end{abstract}

Communicated by O. Ferrarese-Filho.

Marcelo de Almeida Silva

marcelosilva@fca.unesp.br

Claudiana Moura dos Santos

claudianabio@hotmail.com

1 Department of Crop Production and Breeding, College of Agricultural Sciences, São Paulo State University (UNESP), PO Box 237, Botucatu, SP 18603-970, Brazil
(CAT), and ascorbate peroxidase (APX) enzymes in most of the cultivars, confirming the importance of interaction of these enzymes against oxidative stress damages.

Keywords Saccharum spp. - Drought Photosynthetic pigments $\cdot$ Antioxidant enzymes $\cdot$ Methyl viologen

$\begin{array}{ll}\text { Abbreviations } \\ +\mathrm{D} & \text { Water-deficit treatment } \\ \Psi_{\mathrm{w}} & \text { Leaf water potential } \\ \mathrm{APX} & \text { Ascorbate peroxidase } \\ \mathrm{C} & \text { Control treatment } \\ \mathrm{Car} & \text { Carotenoids } \\ \mathrm{CAT} & \text { Catalase } \\ \mathrm{Chl} a & \text { Chlorophyll } a \\ \mathrm{Chl} b & \text { Chlorophyll } b \\ \mathrm{Chl} \text { total } & \text { Total } \text { Chlorophyll } \\ \mathrm{DW} & \text { Dry weight } \\ F_{\mathrm{v}} / F_{\mathrm{m}} & \text { Maximum photochemical efficiency of } \\ & \text { photosystem II } \\ \mathrm{FW} & \text { Fresh weight } \\ \mathrm{GR} & \text { Glutathione reductase } \\ \mathrm{H}_{2} \mathrm{O}_{2} & \text { Hydrogen peroxide } \\ \mathrm{MDHA} & \text { Monodehydroascorbate reductase } \\ \mathrm{NBT} & \text { Nitro blue tetrazolium } \\ \mathrm{PAR} & \text { Photosynthetically active radiation } \\ \mathrm{POX} & \text { Non-specific peroxidase } \\ \text { PQ } & \text { Paraquat } \\ \mathrm{ROS} & \text { Reactive oxygen species } \\ \text { RDM } & \text { Root dry mass } \\ \mathrm{RWC} & \text { Leaf relative water content } \\ \text { SDM } & \text { Shoot dry mass } \\ \text { SPAD } & \text { Estimated chlorophyll content } \\ \text { SOD } & \text { Superoxide dismutase } \\ \text { gs } & \text { Stomatal conductance } \\ & \end{array}$


SW

TDM

Saturated weight

Total dry mass

\section{Introduction}

Crops are often exposed to various environmental stress conditions, such as cold, intense light, drought, air pollution, herbicides, and pathogenic infection, many of which are associated with an excessive growth of reactive oxygen species (ROS) (Apel and Hirt 2004; Darkó et al. 2009). Under severe stress, over production of ROS causes oxidative stress on plants, resulting in increased damages, especially in cell components such as chlorophylls, lipids, proteins, and nucleic acids, and most likely to reduced yield or cell death (Mittler 2002). As a consequence, oxidative damages translate into significant changes affecting growth, development, and productivity of important sugarcane cultures.

Sugarcane, in particular, is an economically important crop because of its world-wide use in the food industry as well as a valuable source for the production of renewable biofuels. It is grown in tropical and subtropical regions in over 90 countries, and Brazil is the world's leading sugarcane producer (Waclawovsky et al. 2010).

Among the environmental stresses, drought or water deficit is one of the biggest problems of present times, affecting a great part of the areas of sugarcane plantations across the world, and is the main crop yield-limiting factor (Jangpromma et al. 2010a; Silva et al. 2014). A consequence of water stress is the limited photosynthesis that leads to the plant exposure to the excess of the energy photosynthesis, which if not dissipated safely may cause overexcitement of the reaction centers of photosystems II and I, raising ROS production in chloroplasts and causing a phytotoxicity effect in plants (Carvalho 2008).

Phytotoxic effects in chloroplasts may also be caused by stress induced by the herbicide paraquat, which, in contact with the plant, acts by accepting electrons from the primary acceptor of photosystem I. Interception of electrons in photosystem I stops the ferredoxin reduction, thus interfering with the reduction of $\mathrm{NADP}^{+}$to NADPH in the stroma, which would be used in the Calvin cycle to reduce $\mathrm{CO}_{2}$ (Ekmekci and Terzioglu 2005; Taiz and Zeiger 2010). When paraquat is photoreduced in photosystem I, it exerts its phytotoxic effects by catalyzing the transfer of electrons to photosystem II from photosystem I and is then oxidized again by the transfer of electrons to $\mathrm{O}_{2}$ in the presence of light. Upon receiving electrons, paraquat reacts with molecular oxygen, producing superoxide radical $\left(\mathrm{O}_{2}^{--}\right)$, resulting in the accumulation of $\mathrm{O}_{2}^{--}$in chloroplasts, which causes oxidative stress in plants (Iturbe-Ormaetxe et al. 1998; Sood et al. 2011).

To protect against the harmful effects of ROS produced during oxidative stress, plants have a complex antioxidant defense system encompassing low-molecular-mass antioxidants, such as hydrophilic molecules, represented by ascorbic acid and reduced glutathione, lipophilic molecules, such as $\alpha$-tocopherol and carotenoids, and antioxidant enzymes such as superoxide dismutase (SOD), catalase (CAT), ascorbate peroxidase (APX), non-specific peroxidase (POX), glutathione reductase (GR), and monodehydroascorbate reductase (MDHA), which act in the reduction of ROS, mitigating the oxidative damages in the plant cell (Mittler 2002; Sharma et al. 2012).

Paraquat besides being widely used as a herbicide desiccant, has been a very useful tool in the research of basic biology of plants, in the simulations of oxidative stress, with successful reported results in maize (Darkó et al. 2009; Shahrtash et al. 2011), wheat (Sedigheh et al. 2011), rice (Guo et al. 2007), in addition to vegetable species such as cucumber (Lin et al. 2011) and pumpkin (Yoon et al. 2011). These studies reported oxidative damages such as photoinhibition, loss of photosynthetic activity, proteins breakdown, reduction of photosynthetic pigments, and chlorosis associated with the activities of the antioxidant enzymes, enabling a better understanding of many protective mechanisms against oxidative stress.

Currently, considerable attention has been given to the selection of sugarcane varieties tolerant to biotic and abiotic stresses, based on the optimum performance of the plant in the antioxidant activity against oxidative stress, as found in studies on water deficit (Patade et al. 2011; Cia et al. 2012), salinization (Gomathi and Rakkiyapan 2011), temperature rise (Srivastava et al. 2012), and flood (Gomathi et al. 2012). However, comparative studies on drought- and paraquat-induced stress involving physiological responses and biochemical damages in sugarcane plants are still scarce. Thus, our objective was to compare the physiological and biochemical responses of sugarcane grown under water stress with plants submitted to oxidative stress. The herbicide paraquat was used to induce oxidative stress. The assays can help to better understand the sugarcane antioxidant network and to provide a basis for selection of varieties with improved oxidative stress tolerance.

\section{Materials and methods}

\section{Experimental procedure and plant material}

The experiment was conducted in greenhouse. Cultivars were selected from the most representative species grown 
in the Center-South region of Brazil, according to Chapola et al. (2009). Four sugarcane cultivars were used: RB92579, SP83-2847, SP81-3250, and IAC91-5155.

The plants were obtained from shoot buds from seedpieces of the same age. The seedpieces were planted in 22-L pots and filled with Plantmax ${ }^{\circledR}$ substrate (sterile product prepared with expanded vermiculite and organic material). During the experiment, the average air temperature was $27.4 \pm 5^{\circ} \mathrm{C}$ and the daily average relative humidity was $62.8 \%$, while the daily average of photosynthetically active radiation (PAR) was $800 \mu \mathrm{mol} \mathrm{m} \mathrm{m}^{-2} \mathrm{~s}^{-1}$.

Eighty-five days after planting, the cultivars were submitted to three experiments: appropriate water regime (control, C), water deficit $(+\mathrm{D})$, and induced stress by herbicide paraquat (+PQ). In the control experiment $(C)$, the plants were irrigated as necessary to keep the optimum moisture content in the substrate, i.e., around $22 \%$ (corresponding to $100 \%$ of the field capacity), and in the experiment with water deficit $(+D)$ watering was interrupted for 15 days until moisture content in the substrate reached $10 \%$. To monitor the moisture in the pots, $\mathrm{ECH} 2 \mathrm{O}$ moisture sensor (Decagon, Washington, USA) was used, which is considered an effective device for such control (Silva et al. 2013).

The experiment with paraquat (+PQ) occurred 85 days after planting, simultaneously with the beginning of the experiment with water deficit. The plant of each pot was entirely sprayed with paraquat at a concentration of $150 \mu \mathrm{M}$, and the effect was evaluated $24 \mathrm{~h}$ after application.

Before this experiment, preliminary studies were conducted in leaf disks $\left(0.69 \mathrm{~cm}^{2}\right)$, were floated in PQ solutions $(0,50,100,150,200 \mu \mathrm{M})$ for different durations $(0$, 24, 48, 72, and $96 \mathrm{~h}$ ), and the whole experiment was conducted under the constant light exposure of $120 \mu \mathrm{mol} \mathrm{m}{ }^{-2} \mathrm{~s}^{-1}$. Chlorophyll degradation (a measure of PQ resistance) was monitored using reading spectrophotometer. The $150 \mu \mathrm{M}$ PQ solution was found to be the most optimum screening concentration since it triggered quantifiable changes in chlorophyll content within $24 \mathrm{~h}$.

The experimental design used was totally randomized in $4 \times 3$ factorial design, the factors being: four cultivars and three conditions of stress (control $=\mathrm{C}$, water deficit $=+D$, and paraquat $+P Q$ ), with four replicates. The physiological evaluations and collection of samples for biochemical analyses were performed in the $+\mathrm{D}$ experiment 15 days after the induced stress, and in the $+P Q$ experiment $24 \mathrm{~h}$ after application of the herbicide.

A second stage of the experiment, in the same period of time, was conducted with leaf segments to evaluate the photosynthetic pigment degradation after the application of paraquat, compared with the plants submitted to water deficit $(+D)$ for 15 days. For this purpose, leaves of the plants were cut into disks $\left(0.69 \mathrm{~cm}^{2}\right)$, and half of these leaf disks were immersed in a solution of paraquat for $24 \mathrm{~h}$ in Petri dishes with $150 \mu \mathrm{M}$ dissolved in $30 \mathrm{~mL}$ of deionized water, and the other half was immersed in deionized water only. Then, all samples were kept in a growth chamber at a temperature of $27^{\circ} \mathrm{C}$ and continuous light intensity of $120 \mu \mathrm{mol} \mathrm{m} \mathrm{m}^{-2} \mathrm{~s}^{-1}$ for $24 \mathrm{~h}$.

\section{Physiological trait evaluations}

For leaf relative water content (RWC), we determined fresh weight (FW), saturated weight (SW), and dry weight (DW) in leaf disks extracted from the +2 leaves. RWC was estimated according to the following equation: $\mathrm{RWC}=[(\mathrm{FW}-\mathrm{DW}) /(\mathrm{SW}-\mathrm{DW})] \times 100$. Leaf water potential $\left(\Psi_{\mathrm{w}}\right)$ was evaluated between 10 a.m. and noon using a Scholander pressure chamber (SoilMoisture Equipment, Santa Barbara, CA, USA). Plants were collected and separated into shoot and roots. Shoot dry mass (SDM), root dry mass (RDM), and total dry mass (TDM) were determined after drying the plant tissues in an oven at $65{ }^{\circ} \mathrm{C}$ for 6 days.

The maximum photochemical efficiency of photosystem II $\left(F_{\mathrm{v}} / F_{\mathrm{m}}\right)$ was determined by means of a portable fluorometer (Opti-Sciences, Inc., Hudson, NH, USA) after adapting the leaves in darkness for $30 \mathrm{~min}$ using leaf clipping. Readings were taken with saturating light pulses of $1 \mathrm{~s}$ to close the reaction centers of PSII, according to the method described by Maxwell and Johnson (2000). Stomatal conductance, gs $\left(\mathrm{mmol} \mathrm{m}^{-2} \mathrm{~s}^{-1}\right)$ was determined by means of a porometer (Decagon Devices Inc., Pullman, WA, USA). Readings were taken at the middle region of a fully expanded leaf +1 at the abaxial side. Estimated chlorophyll contents via SPAD reading (SPAD index) were determined using a SPAD-502 chlorophyll meter (Minolta Corp., Ramsey, NJ, USA). Readings were taken at the middle region of a fully expanded leaf +1 in $10-12 \mathrm{~h}$ in the control and drought experiments and $24 \mathrm{~h}$ following the application of paraquat, measuring one leaf of each plant.

\section{Proline, carbohydrate, and pigment measurement}

The free proline in the lyophilized leaf tissue was measured by a reaction with ninhydrin according to the method of Bates et al. (1973), with modifications. Approximately $100 \mathrm{mg}$, dry weight, of tissue was macerated in liquid nitrogen and homogenized in $8 \mathrm{~mL}$ of $118 \mathrm{mM}$ sulfosalicylic acid. The homogenate was then centrifuged at $3000 \mathrm{~g}$ for $10 \mathrm{~min}$ at $25^{\circ} \mathrm{C}$, and the supernatant was used for the quantitative analysis. Readings of absorbance was taken at $520 \mathrm{~nm}$. Only toluene was used as blank and pure proline as standard. 
Total soluble carbohydrates were determined according to the method described by Dubois et al. (1956) using $100 \mathrm{mg}$ of dried leaf material. $500 \mu \mathrm{L}$ of extract was combined with $1 \mathrm{~mL} 0.56 \mathrm{M}$ phenol and $5 \mathrm{~mL}$ of concentrated sulfuric acid. The carbohydrates were quantified by measuring the absorbance at $490 \mathrm{~nm}$, using D-(+)-glucose as a standard.

The analysis of chlorophylls $a, b$, total and carotenoids was according to the method described by Lichtenthaler (1987), where the extract was obtained using leaf disks with $0.69 \mathrm{~cm}^{2}$ immersed in $2 \mathrm{~mL}$ of dimethylformamide solvent, and subsequent reading of absorbance was taken by a spectrophotometer at 480, 647, and $664 \mathrm{~nm}$ wavelengths.

\section{Assay of enzymatic antioxidants}

The superoxide dismutase (SOD, E.C.1.15.1.1) activity was determined according to the method described by Beauchamp and Fridovich (1973). The extract was obtained from $300 \mathrm{mg}$ of fresh leaf tissue, and $100 \mu \mathrm{L}$ was taken from the vegetable extract and put into the reaction medium, and then the homogenate was centrifuged at $14,000 \mathrm{~g}$ for $15 \mathrm{~min}$ at $4{ }^{\circ} \mathrm{C}$. This medium was prepared with $50 \mathrm{mM}$ potassium phosphate buffer ( $\mathrm{pH} 7.8$ ), $100 \mathrm{nM}$ EDTA, $75 \mu \mathrm{M}$ nitro blue tetrazolium (NBT), $13 \mathrm{mM}$ methionine and $2 \mu \mathrm{M}$ riboflavin, and final volume of $3 \mathrm{~mL}$ distilled water. Then, readings were taken by a spectrophotometer at $560 \mathrm{~nm}$.

The catalase (CAT, EC 1.11.1.6) activity was determined according to Havir and Mchale (1987) with some changes. The extract was obtained following the method described by Kar and Mishra (1976), and from $400 \mathrm{mg}$ of leaf material $150 \mu \mathrm{L}$ was taken from the extract and put in the reaction medium with $50 \mathrm{mM}$ potassium phosphate

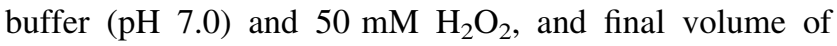
$3 \mathrm{~mL}$ distilled water. Once homogenized, the extract was centrifuged at $14,000 \mathrm{~g}$ for $15 \mathrm{~min}$ at $4{ }^{\circ} \mathrm{C}$, and the supernatant was used for the analysis. Readings of absorbance were taken at $240 \mathrm{~nm}$ for $1 \mathrm{~min}$ and the decrease of $\mathrm{H}_{2} \mathrm{O}_{2}$ concentration was observed. An $\mathrm{H}_{2} \mathrm{O}_{2}$ extinction coefficient of $36 \mathrm{mM}^{-1} \mathrm{~cm}^{-1}$ at $240 \mathrm{~nm}$ was adopted.

The ascorbate peroxidase (APX, EC 1.11.1.11) activity was determined according to the method described by Nakano and Asada (1981) with some changes. The extract was obtained from $20 \mathrm{mg}$ of fresh leaves, and $30 \mu \mathrm{L}$ of the extract was taken and put into the reaction medium, and then the homogenate was centrifuged at $14,000 \mathrm{~g}$ for $15 \mathrm{~min}$ at $4{ }^{\circ} \mathrm{C}$. This medium was prepared with $50 \mathrm{mM}$ potassium phosphate buffer $(\mathrm{pH} 7.5), 0.05 \mathrm{mM} \mathrm{H}_{2} \mathrm{O}_{2}$, and $0.5 \mathrm{mM}$ sodium ascorbate, and the volume was completed with $3 \mathrm{~mL}$ of distilled water. Readings of absorbance were taken at $290 \mathrm{~nm}$ for $1 \mathrm{~min}$, observing the decrease of ascorbate concentration. An ascorbate extinction coefficient of $2.8 \mathrm{mM}^{-1} \mathrm{~cm}^{-1}$ at $290 \mathrm{~nm}$ was used. Soluble proteins were quantitatively determined following the method of Bradford (1976).

\section{Statistical analysis}

The experimental data were submitted to the analysis of variance ( $F$ test) and means were compared by the Tukey test at $5 \%$ probability. Pearson's $(r)$ correlation was used to verify the relation between the physiological variables and the biochemical components in the studied period.

\section{Results}

\section{Responses of physiological trait to stress induced by water stress and paraquat}

After 15 days of water suppression, the lowest leaf relative water content (RWC) was observed in cultivar RB92579, with a mean RWC of $74 \%$, followed by SP81-3250 with a RWC of $77.3 \%$ and SP83-2847 with a RWC of $84.5 \%$ (Fig. 1a). There was a marked decrease in leaf water potential $\left(\Psi_{\mathrm{w}}\right)$ under water deficit in cultivar SP81-3250 $(-2.3 \mathrm{MPa})$, followed by SP83-2847 (-1.8 MPa), RB92579 (-1.7 MPa), and IAC91-5155 (-1.7 MPa) (Fig. 1b).

Under the action of paraquat $(+\mathrm{PQ})$, smaller reductions of the maximum photochemical efficiency of photosystem II $\left(F_{\mathrm{v}} / F_{\mathrm{m}}\right)$ were observed in cultivars SP83-2847 and IAC91-5155, reaching values of 0.77 and 0.71 , respectively. Lower values of the $F_{\mathrm{v}} / F_{\mathrm{m}}$ ratio were observed in cultivars RB92579 (0.64) and SP81-3250 (0.63), corresponding to reductions of 19 and $20.2 \%$, respectively (Fig. 2a). Under water deficit (+D) for 15 days, similar mean values of $F_{\mathrm{v}} / F_{\mathrm{m}}$ were found for the cultivars SP813250 (0.63) and RB92579 (0.66), indicating a greater photoinhibition and sensitivity of these cultivars to both stress conditions, while cultivars IAC91-5155 and SP832847 presented $F_{\mathrm{v}} / F_{\mathrm{m}}$ means of 0.74 and 0.76 , respectively, i.e., close to the control (Fig. 2a).

With respect to stomatal conductance, a decrease of gs values in the plants submitted to paraquat stress $(+P Q)$ and water deficit (+D) was found (Fig. 2b). Results indicate greater decreases of gs in cultivars SP81-3250 and RB92579, of 84.6 and $68.6 \%$, respectively, when treated with $+\mathrm{PQ}$. But reductions of $g s$ were also observed in cultivars SP83-2847 (36.8\%) and IAC91-5155 (47.8\%) under + PQ-induced stress (Fig. 2b). In the same period, under water stress, the reduction of stomatal conductance was found in all cultivars, IAC91-5155 (73.8\%), SP83- 


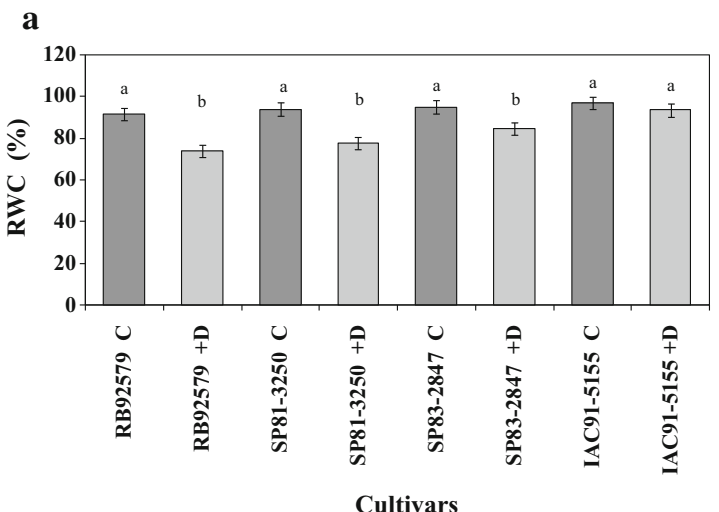

Fig. 1 Leaf relative water content, RWC (a) and leaf water potential, $\Psi_{\mathrm{w}}(\mathbf{b})$, in cultivars RB92579, SP81-3250, SP83-2847, and IAC915155 subjected to adequate water regimens (control, C) and water

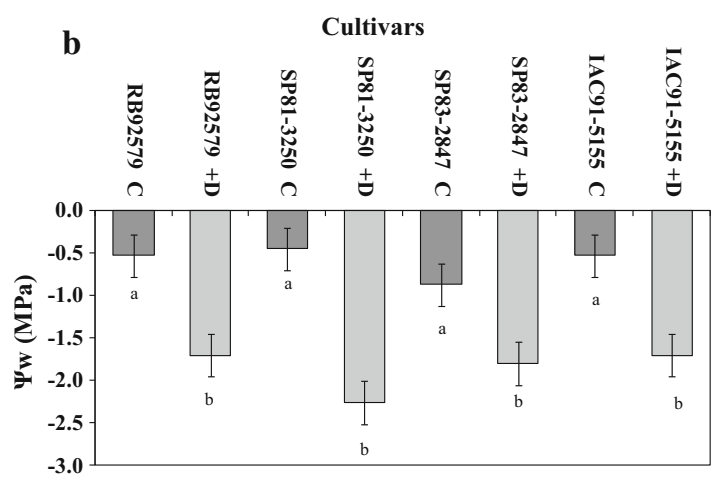

deficit $(+\mathrm{D})$ for 15 days. Means followed by the same letter do not differ at $5 \%$ probability by Tukey test

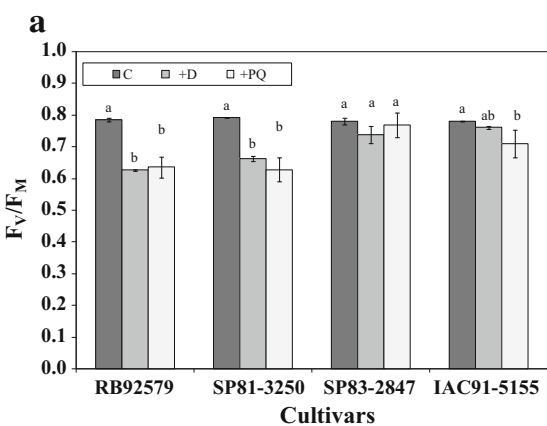

b

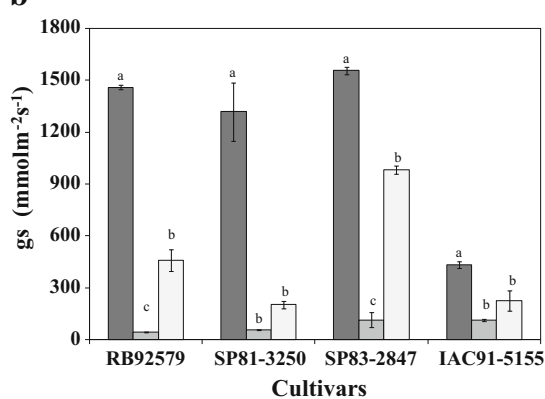

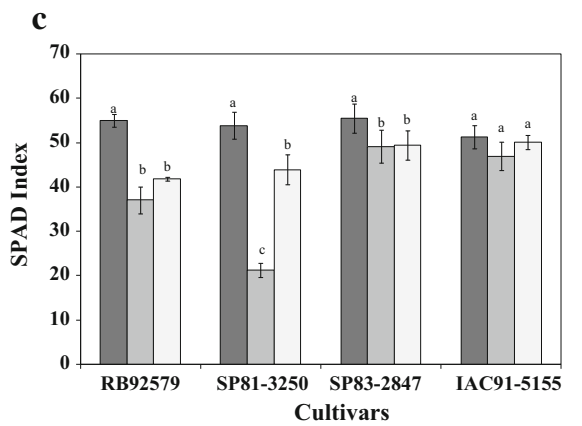

Fig. 2 Maximum photochemical efficiency of photosystem II, $F_{\mathrm{v}} / F_{\mathrm{m}}$ (a), stomatal conductance, gs (b), and chlorophyll estimated content, SPAD index (c) in cultivars RB92579, SP81-3250, SP83-2847, and IAC91-5155 submitted to appropriate water regime (control, C),

2847 (92.6 \%), RB92579 (97\%), and SP81-3250 (96\%) (Fig. 2b).

It can be seen that gs presented positive correlation with $F_{\mathrm{v}} / F_{\mathrm{m}}\left(0.64^{* *}\right)$ and SOD enzyme $\left(0.60^{*}\right)$ under + PQ-induced stress, and under water deficit $g s$ correlated positively with $F_{\mathrm{v}} / F_{\mathrm{m}}(0.64 * *)$, SPAD $(0.57 *)$, total chlorophyll $(0.67 * *)$, and antioxidant enzymes SOD $(0.70 *)$, CAT $\left(0.56^{*}\right)$, and APX $\left(0.56^{* *}\right)$ (Table 1), indicating that the reduction of stomatal conductance is associated with the oxidative damages found in both stress conditions.

Regarding the estimated chlorophyll content no difference was found between experiments $+\mathrm{D}$ and $+\mathrm{PQ}$ in cultivar IAC91-5155. Cultivar SP83-2847, despite a difference, maintained mean values of $\sim 50$ for SPAD index (Fig. 2c). Cultivars RB92579 and SP81-3250 showed reductions of 24 and $18.5 \%$, respectively, of SPAD index in the experiment with paraquat, and of 33 and $60.6 \%$, respectively, under water deficit (Fig. 2c), which indicates a more significant sensitivity of these cultivars to water stress with regard to this physiological attribute. water deficit $(+\mathrm{D})$, and concentration of $150 \mu \mathrm{M}$ of paraquat $(+\mathrm{PQ})$ for $24 \mathrm{~h}$. Means followed by the same letter do not differ at $5 \%$ probability by Tukey test

Under water deficit, it was found a positive correlation between the SPAD index and $F_{\mathrm{v}} / F_{\mathrm{m}}(0.64 *)$, total chlorophyll $\left(0.97^{* *}\right)$, carotenoids $\left(0.77^{* *}\right)$, and CAT enzyme $(0.59 *)$. When treated with $+\mathrm{PQ}$, the SPAD correlated positively with $F_{\mathrm{v}} / F_{\mathrm{m}}\left(0.60^{* *}\right)$ and with the antioxidant enzymes SOD $\left(0.70^{* *}\right)$, CAT $\left(0.70^{* *}\right)$, and APX $\left(0.56^{* *}\right)$, and inversely with carotenoids $\left(-0.51^{*}\right)$ (Table 1$)$. Such positive correlations suggest that the reduced photosynthetic pigments are associated with the damages caused by photoinhibition and inactivation of antioxidant enzymes during the oxidative stress in this study.

\section{Effects of water stress and paraquat-induced stress on photosynthetic pigments}

The decreased chlorophyll contents were more pronounced under paraquat-induced stress in cultivar SP81-3250, with a reduction of $65 \%$ for $\mathrm{Chl} a, 55.4 \%$ for $\mathrm{Chl} b$, and $62.4 \%$ for Chl total, and in cultivar RB92579, $55.4 \%$ for $\mathrm{Chl} a, 50 \%$ for $\mathrm{Chl} b$, and $60 \% \mathrm{Chl}$ total (Fig. 3a, b and 
Table 1 Pearson correlation coefficients between the physiological and biochemical variables of sugarcane submitted to appropriate water regime $(C)$, water deficit $(+D)$, and oxidative stress induced by paraquat (+PQ)

\begin{tabular}{|c|c|c|c|c|c|c|c|c|}
\hline Variables & SPAD & $F_{\mathrm{V}} / F_{\mathrm{M}}$ & $\mathrm{Chl}_{\text {total }}$ & $\mathrm{C}_{\mathrm{ar}}$ & Prol & SOD & CAT & APX \\
\hline \multicolumn{9}{|l|}{ Control } \\
\hline gs & $0.62 *$ & 0.14 & $0.67 *$ & $0.85 * *$ & $-0.81 * *$ & -0.19 & -0.60 & $-0.67 *$ \\
\hline SPAD & & 0.08 & $0.70 * *$ & $0.65^{*}$ & -0.55 & -0.06 & -0.43 & -0.28 \\
\hline$F_{\mathrm{V}} / F_{\mathrm{M}}$ & & & 0.24 & 0.48 & 0.24 & $-0.63^{*}$ & -0.08 & -0.39 \\
\hline $\mathrm{Chl}_{\text {total }}$ & & & & $0.85 * *$ & $-0.67 *$ & -0.47 & 0.54 & 0.30 \\
\hline $\mathrm{C}_{\mathrm{ar}}$ & & & & & $-0.64 *$ & -0.50 & -0.44 & $-0.59 *$ \\
\hline Prol & & & & & & 0.29 & 0.28 & -0.01 \\
\hline SOD & & & & & & & -0.42 & 0.14 \\
\hline CAT & & & & & & & & $0.66^{* *}$ \\
\hline \multicolumn{9}{|c|}{ Drought stress } \\
\hline gs & $0.57 *$ & $0.64 *$ & $0.67 * *$ & $0.85^{* *}$ & $-0.61^{*}$ & $0.70^{*}$ & $0.56 *$ & $0.56 * *$ \\
\hline SPAD & & $0.64 *$ & $0.97 * *$ & $0.77 * *$ & -0.53 & 0.30 & $0.59 *$ & 0.31 \\
\hline$F_{\mathrm{V}} / F_{\mathrm{M}}$ & & & $0.64 *$ & $0.54 *$ & $-0.64 *$ & $0.80 * *$ & $0.77 * *$ & $0.77 * *$ \\
\hline $\mathrm{Chl}_{\text {total }}$ & & & & $0.74 * *$ & -0.50 & 0.3 & $0.54 *$ & $0.55^{*}$ \\
\hline $\mathrm{C}_{\mathrm{ar}}$ & & & & & $-0.72 * *$ & 0.24 & 0.22 & 0.22 \\
\hline Prol & & & & & & $-0.60 * *$ & -0.19 & $-0.80 * *$ \\
\hline SOD & & & & & & & $0.68 * *$ & $0.80 * *$ \\
\hline CAT & & & & & & & & $0.62 *$ \\
\hline \multicolumn{9}{|c|}{ Paraquat stress } \\
\hline gs & 0.25 & $0.64 * *$ & 0.35 & 0.19 & $0.50 *$ & $0.60 *$ & 0.02 & 0.05 \\
\hline SPAD & & $0.60 * *$ & 0.23 & $-0.51^{*}$ & 0.24 & $0.70^{* *}$ & $0.70 * *$ & $0.56^{* *}$ \\
\hline$F_{\mathrm{V}} / F_{\mathrm{M}}$ & & & 0.15 & 0.03 & 0.43 & $0.88 * *$ & $0.56^{*}$ & 0.48 \\
\hline $\mathrm{Chl}_{\text {total }}$ & & & & -0.05 & 0.01 & 0.04 & 0.06 & $-0.72 *$ \\
\hline $\mathrm{C}_{\mathrm{ar}}$ & & & & & 0.06 & -0.13 & -0.35 & -0.28 \\
\hline Prol & & & & & & 0.46 & $0.57 *$ & $0.52 *$ \\
\hline SOD & & & & & & & $0.72 * *$ & 0.44 \\
\hline CAT & & & & & & & & $0.70 * *$ \\
\hline
\end{tabular}

Stomatal conductance (gs), maximum photochemical efficiency of photosystem II $\left(F_{\mathrm{v}} / F_{\mathrm{m}}\right)$, chlorophyll estimated content (SPAD index), total chlorophyll (Chl total) and carotenoids (Car), proline (Prol), superoxide dismutase (SOD), catalase (CAT), ascorbate peroxidase (APX)

* Significant at $P<0.05$ and $* *$ significant at $P<0.01$ c). Reduced pigments were also found in cultivar IAC915155, with decreased concentrations of Chl $a$, Chl $b$, and Chl total of 54, 7, $47.7 \%$, respectively, and in cultivar SP83-2847 of 51.7, 37.3, $42.1 \%$, respectively (Fig. 3), but cultivars IAC91-5155 and SP83-2847 had lower reductions when compared to other cultivars.

Cultivars IAC91-5155 and SP83-2847 showed no differences in chlorophyll levels in the experiments with and without water deficit, suggesting a better capacity of these varieties to maintain chlorophyll levels during stress. But in cultivars RB92579 and SP81-3250 under water deficit, the reduced contents of Chl $a$, Chl $b$, and Chl total of 41.3, 22, 36.3, and 53.5, 46.8, 51.6\%, respectively (Fig. 3), indicate high chlorophyll degradation. In addition, an inverse correlation between total chlorophyll and APX enzyme $(-0.72 *)$ in the $+\mathrm{PQ}$ experiment (Table 1 ) was observed, suggesting that in the paraquat-induced stress there was chlorophyll degradation due to the oxidative effect, which prompted an overproduction of APX to fight damages in chloroplasts.

Under water deficit, a positive correlation between Chl total and gs $\left(0.67^{* *}\right), F_{\mathrm{v}} / F_{\mathrm{m}}\left(0.64^{*}\right)$, CAT $\left(0.54^{*}\right)$, and APX $\left(0.55^{*}\right)$ (Table 1) was found, indicating that the increased photoinhibition and stomata closure contributed to chlorophyll degradation as a result of increased oxidative stress, also reducing the antioxidant enzymes activity in drought conditions.

Carotenoids had a different behavior under paraquatinduced stress and water deficit. Under paraquat $(+\mathrm{PQ})$ there was an increased carotenoid production, of $55.6 \%$ in RB92579, 53.6 \% in SP81-3250, $31.4 \%$ in SP83-2847, and $67.2 \%$ in IAC91-5155 (Fig. 3d). On the other hand, the carotenoid values found during the 15 days under water stress were reduced by 27.4 and $29.6 \%$ in cultivars 


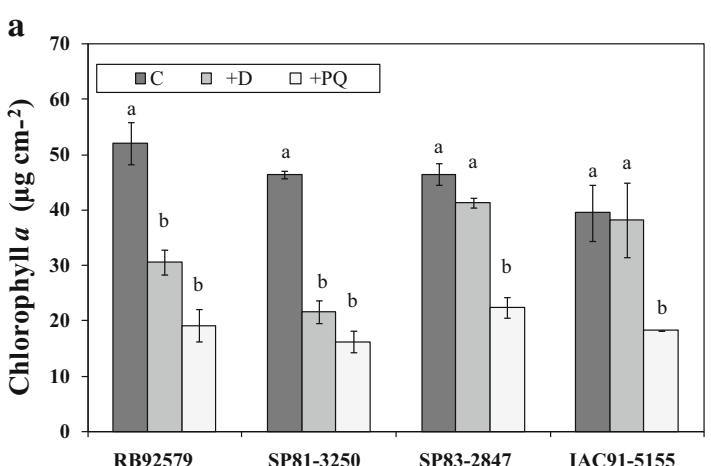

c

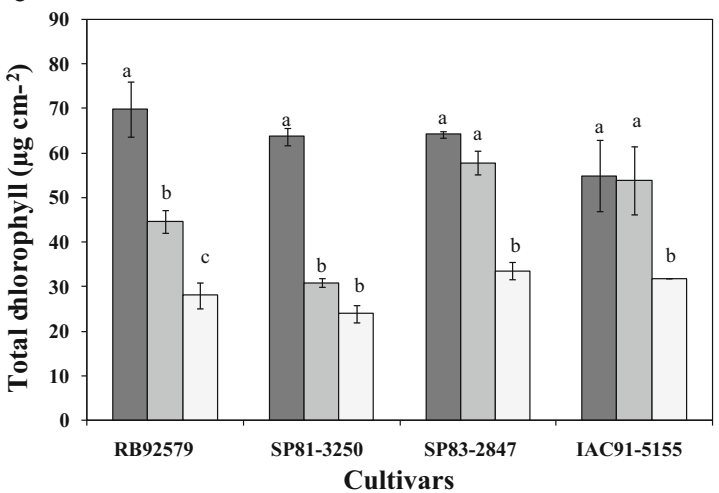

Fig. 3 Contents of chlorophyll $a$ (a), chlorophyll $b$ (b), total chlorophyll (c), and carotenoids (d) in cultivars RB92579, SP813250, SP83-2847, and IAC91-5155 submitted to appropriate water

RB92579 and SP81-3250, respectively, while in cultivars IAC91-5155 and SP83-2847 the values were close to the control, but a small increase of $11 \%$ in IAC $91-5155$ could be observed (Fig. 3d).

\section{Effects of water stress and paraquat-induced stress on carbohydrate, proline, and protein concentrations}

In general, + PQ-induced oxidative stress caused a reduction in total soluble carbohydrates in cultivars SP81-3250 (6\%), RB92579 (21.4\%), and SP83-2847 (11\%) (Fig. 4a). On the other hand, cultivar IAC91-5155 showed similar values to the control, and was not affected by $+\mathrm{PQ}-$ induced stress. Under water deficit, inverse responses were found, creating an increase of sugar content in cultivars RB92579 (48.1\%), SP83-2847 (18\%), and IAC91-5155 (25.3\%). But cultivar SP81-3250 presented a reduction of $14 \%$ (Fig. 4a).

Different effects were also found for proline in $+\mathrm{D}$ and $+\mathrm{PQ}$ experiments. In the paraquat experiment, a reduction of proline occurred in cultivars RB92579 (26.7 \%), SP81$3250(10.8 \%)$, SP83-2847 (53.8 \%), and IAC-5155 (47 \%) (Fig. 4b). In the period of 15 days under water deficit,
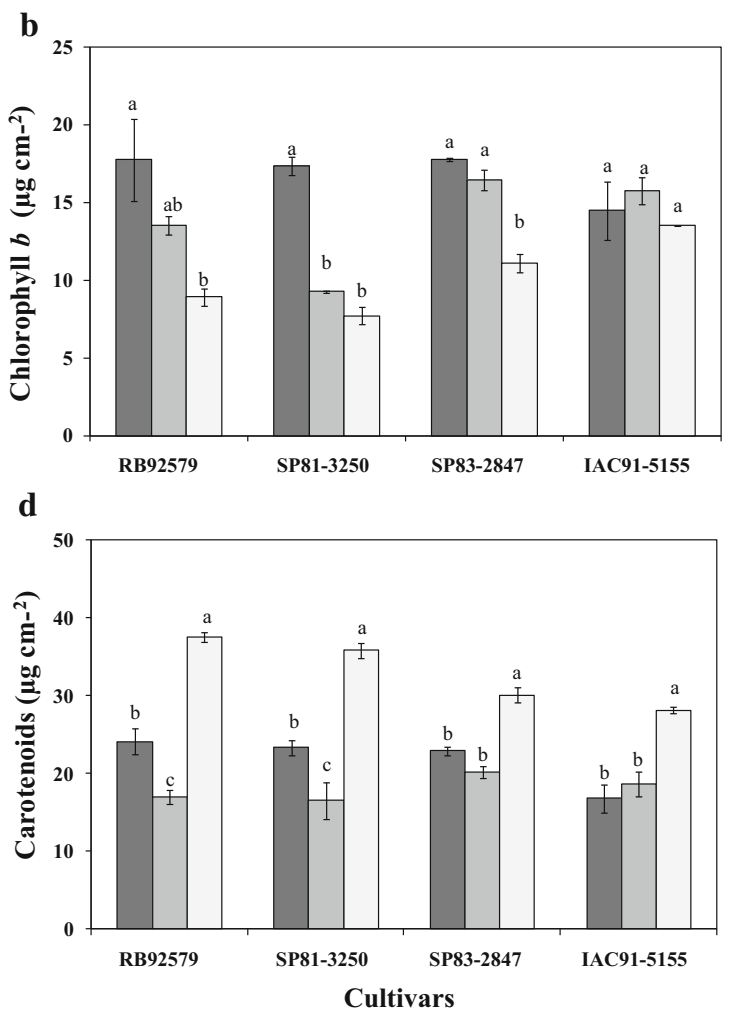

regime (control, C), water deficit ( $+\mathrm{D}$ ), and concentration of $150 \mu \mathrm{M}$ of paraquat (+PQ) for $24 \mathrm{~h}$ using leaf disks. Means followed by the same letter do not differ at $5 \%$ probability by the Tukey test

cultivar IAC91-5155 showed proline concentration almost similar to the control. But the rates of proline increased significantly in cultivars RB92579 (102\%), SP81-3250 (20.1\%), and SP83-2847 (26\%) under drought (Fig. 4b).

In this study, a response pattern similar to the altered concentrations of soluble proteins in the four cultivars when submitted to the water deficit or $+\mathrm{PQ}$ experiments was observed (Fig. 4c). Water deficit caused a reduction in protein concentrations, of $36.8 \%$ in SP81-3250, $33.4 \%$ in RB92579, and $26.6 \%$ in SP83- 2847. In the +PQ experiment protein reductions were observed in SP81-3250 (52.4 \%), RB92579 (40.5 \%), and in SP83-2847 (22.2 \%). But cultivar IAC91-5155 was not affected by $+\mathrm{D}$ or $+\mathrm{PQ}$ treatments, maintaining means close to the control (Fig. 4c).

\section{Response of antioxidant enzymes to oxidative stress induced by water deficit or paraquat in sugarcane}

Such different responses can also be observed in the correlations. Under water stress, proline was inversely correlated with gs $(-0.61 *), \quad F_{\mathrm{v}} / F_{\mathrm{m}}(-0.64 *)$, carotenoids $(-0.72 * *)$, antioxidant enzymes SOD $(-0.60 * *)$ and APX $\left(-0.80^{* *}\right)$ (Table 1), suggesting that this amino acid 

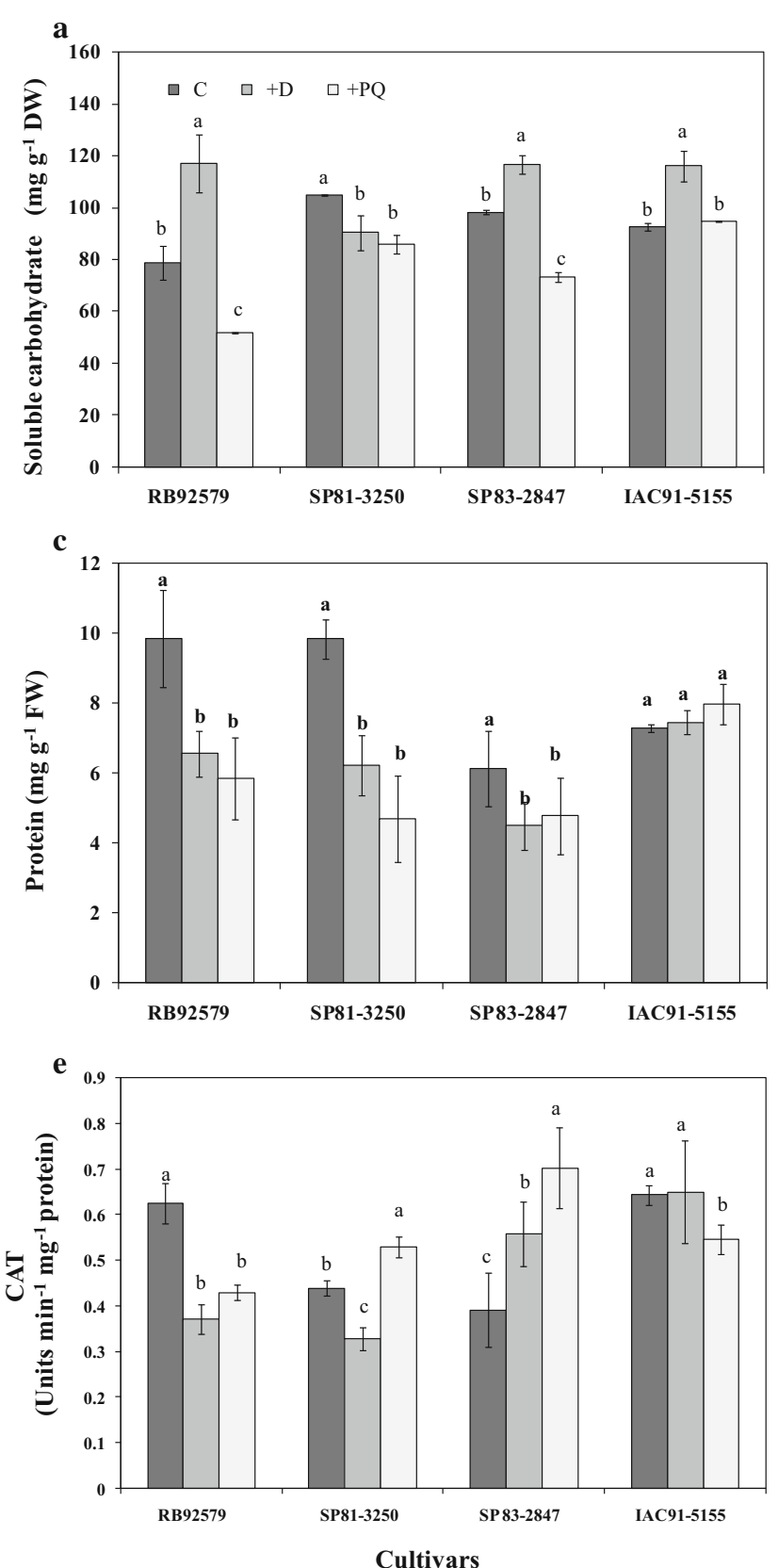

Fig. 4 Concentrations of soluble carbohydrate (a), proline (b), protein (c), and antioxidant enzymes, superoxide dismutase, SOD (d), catalase, CAT (e), and ascorbate peroxidase, APX (f) in cultivars RB92579, SP81-3250, SP83-2847, and IAC91-5155 submitted to

played the role of antioxidant agent due to its increased production and a reduction of the stomatal conductance, $F_{\mathrm{v}} / F_{\mathrm{m}}$, and antioxidant enzymes caused by oxidative stress. When the plants were treated with $+\mathrm{PQ}$, proline correlated positively with CAT $(0.57 *)$ and APX $(0.52 *)$ (Table 1$)$, indicating reduction in these variables in response to more intense oxidative stress.

In all cultivars, an increased activity of SOD caused by oxidative stress induced by $+\mathrm{PQ}$ and $+\mathrm{D}$ was observed. b
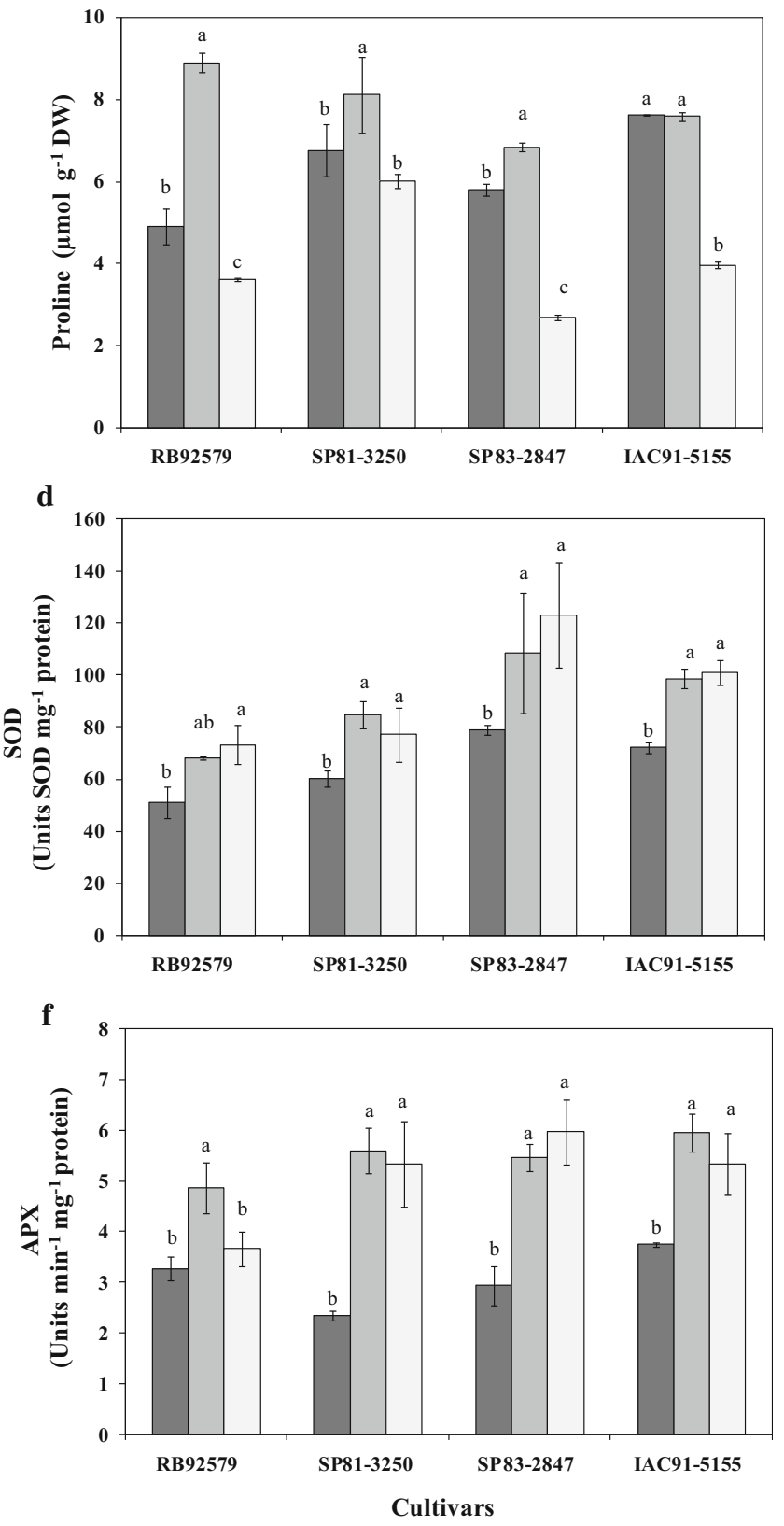

appropriate water regime (control, C), water deficit $(+\mathrm{D})$, and concentration of $150 \mu \mathrm{M}$ of paraquat $(+\mathrm{PQ})$ for $24 \mathrm{~h}$. Means followed by the same letter do not differ at $5 \%$ probability by Tukey test

Increases in SOD activity in the $+\mathrm{PQ}$ experiment were of $43.5 \%$ in cultivar RB92579, of $28 \%$ in SP81-3250, $56 \%$ in SP83-2847, and $40 \%$ in IAC91-5155. In the droughtinduced experiment increases in SOD levels were of $33.6 \%$ for RB92579, $40.3 \%$ for SP81-3250, $37.5 \%$ for SP83-2847, and $36.6 \%$ for IAC91-5155 (Fig. 4d), signaling oxidative stress in both experiments.

Such important role of SOD as indispensable for ROS detoxification during oxidative stress in sugarcane can be 
demonstrated by the positive correlations of this enzyme with gs $\left(0.60^{*}\right)$, SPAD index $\left(0.70^{* *}\right), F_{\mathrm{v}} / F_{\mathrm{m}}\left(0.80^{* *}\right)$, and CAT $(0.72 * *)$ (Table 1$)$ in plants under paraquat-induced stress. When submitted to water stress, SOD correlated positively with gs $(0.70 *), F_{\mathrm{v}} / F_{\mathrm{m}}\left(0.80^{* *}\right)$, CAT $\left(0.68^{* *}\right)$, and APX enzymes $(0.80 * *)$ (Table 1$)$.

Concerning the catalase enzyme activity, the cultivars presented different behaviors in $+\mathrm{D}$ and $+\mathrm{PQ}$ experiments (Fig. 4e). Under oxidative stress induced by +PQ the CAT levels increased by $20.4 \%$ in cultivar SP81-3250 and $79.5 \%$ in SP83-2847. But reductions in the CAT activity were found in cultivars RB92579 (30.6\%) and IAC91$5155(14 \%)$. Under water stress, a reduction of the CAT activity was observed in cultivars SP81-3250 (25\%) and RB92579 (40.3\%). In cultivar SP83-2847 an increase in the CAT activity of $43.6 \%$ occurred, and IAC 91-5155 showed no alterations in CAT under water stress condition (Fig. 4e).

An increase in APX activity was observed in all cultivars under water stress or paraquat. In the +PQ experiment, the highest APX increase was in cultivar SP81-3250 (127\%), followed by $\operatorname{SP83-2847~(104\% ,)~and~IAC91-~}$ $5155(42.4 \%)$, and the lowest increase was found in RB92579 (12\%) (Fig. 4e). Similar behaviors were found under water stress with APX increases of $138 \%$ in cultivar SP81-3250, $86 \%$ in SP83-2847, 58.6 \% in IAC91-5155, and $48.6 \%$ in RB92579 (Fig. 4e), indicating a good performance of this enzyme against oxidative stress in both conditions. In addition, the APX enzyme correlated positively with CAT of $0.70^{* *}$ and $0.62 *$ in the plants treated with $+\mathrm{PQ}$ and under water stress, respectively (Table 1), which confirms the importance of the interaction of these enzymes against oxidative stress damages.

\section{Dry mass production}

Water stress reduced the dry matter in the four cultivars but lower values were observed, i.e., the greater plant reductions, in the shoot, root, and total dry matter of RB92579 (74, 61.6, and $72.7 \%$, respectively) and $\operatorname{SP} 81-3250$ (73.1, 69, and
$72.6 \%$, respectively) compared to SP83-2847 (57.7, 45.6, and $58.7 \%$, respectively) and IAC91-5155 (52.1, 37.6, and $50.6 \%$, respectively) (Table 2).

\section{Discussion}

The normal RWC in the IAC91-5155 cultivar under water deficit is a good indicator of cell and leaf tissue hydration (Fig. 1), and suggests that the plant is under osmotic adjustment, which is a crucial factor for optimal physiological functions such as stomatal control (Gorai et al. 2010). The high RWC reduction in cultivars RB92579 and SP81-3250 is a strong indication of these plants' sensitivity to drought. A progressive decline in RWC (varying between 80 amd $60 \%$ ) in susceptible sugarcane cultivars subjected to water deficit has also been reported by Silva et al. (2011) and Cia et al. (2012). These studies have shown that high RWC values during water shortages are strongly indicative of tolerance in sugarcane cultivars.

In paraquat-induced stress, greater reductions of $F_{\mathrm{v}} / F_{\mathrm{m}}$ in cultivars RB92579 and SP81-3250, with averages nearly 0.6 was observed (Fig. 2a), suggesting that these plants had severe photooxidative damages $24 \mathrm{~h}$ after the application of paraquat. Such stress conditions may have been highly detrimental to the chloroplast functional integrity, thus causing photoinhibition or photooxidation with destabilization of the reaction center of photosystem I (Maxwell and Johnson 2000; Sedigheh et al. 2011).

Chagas et al. (2008) studied paraquat phototoxicity in cultivar SP80-3280 and found that PQ concentrations above $2 \mathrm{mM}$ for $18 \mathrm{~h}$ after the application of the herbicide had caused significant damage to the photosystems, with high photoinhibition, $F_{\mathrm{v}} / F_{\mathrm{m}}$ close to 0.3 . Reductions of $F_{\mathrm{v}} /$ $F_{\mathrm{m}}$ below 0.7 were also found in wheat leaves when submitted to paraquat-induced stress (Ekmekci and Terzioglu 2005; Sedigheh et al. 2011) and in maize (Darkó et al. 2009).

Cultivars IAC91-5155 and SP83-2847 showed $F_{\mathrm{v}} / F_{\mathrm{m}}$ values higher than 0.7 when treated with paraquat and
Table 2 Dry mass production of four sugarcane cultivars submitted to appropriate water regime (control) and water deficit in greenhouse conditions

\begin{tabular}{|c|c|c|c|c|c|c|}
\hline \multirow[t]{2}{*}{ Cultivars } & \multicolumn{2}{|l|}{ SDM (g) } & \multicolumn{2}{|l|}{ RDM (g) } & \multicolumn{2}{|l|}{ TDM (g) } \\
\hline & Control & Water deficit & Control & Water deficit & Control & Water deficit \\
\hline IAC91-5155 & $717.3^{\mathrm{Ba}}$ & $343.0^{\mathrm{Ab}}$ & $83.78^{\mathrm{Ba}}$ & $52.24^{\mathrm{Ab}}$ & $801.1^{\mathrm{Ba}}$ & $395.2^{\mathrm{Ab}}$ \\
\hline SP83-2847 & $763.3^{\mathrm{ABa}}$ & $303.3^{\mathrm{ABb}}$ & $90.7^{\mathrm{ABa}}$ & $49.3^{\mathrm{ABb}}$ & $854.1^{\mathrm{ABa}}$ & $352.7^{\mathrm{Ab}}$ \\
\hline RB92579 & $797.3^{\mathrm{ABa}}$ & $207.6^{\mathrm{Cb}}$ & $91.2^{\mathrm{ABa}}$ & $35.05^{\mathrm{BCb}}$ & $888.5^{\mathrm{ABa}}$ & $242.7^{\mathrm{Bb}}$ \\
\hline SP81-3250 & $825.6^{\mathrm{Aa}}$ & $222.3^{\mathrm{BCb}}$ & $103.9^{\mathrm{Aa}}$ & $32.3^{\mathrm{Cb}}$ & $929.5^{\mathrm{Aa}}$ & $254.7^{\mathrm{Bb}}$ \\
\hline CV (\%) & 7.0 & & 9.9 & & 6.4 & \\
\hline
\end{tabular}

Identical letters, lower case among treatments in the row and upper case between cultivars in the column, do not differ at $5 \%$ probability by Tukey test

$S D M$ shoot dry mass, $R D M$ root dry mass, $T D M$ total dry mass 
under water stress (Fig. 2a), suggesting that these cultivars tend to have minor photoinhibition damages caused by both stressors and may indicate adequacy or adaptation to stress conditions. This indicates that photoinhibition should not be seen as damage but rather as a protective mechanism that allows dissipate excess thermal energy (Long et al. 1994; Murchie and Niyogi 2011).

Greater reductions of $F_{\mathrm{v}} / F_{\mathrm{m}}$ values under water deficit were also observed in cultivars RB92579 and SP81-3250, with mean values close to 0.6 (Fig. $2 \mathrm{a}$ ). In other researches, sugarcane cultivars under water deficit with mean $F_{\mathrm{v}} / F_{\mathrm{m}}$ values below 0.7 were considered sensitive to drought (Graça et al. 2010; Silva et al. 2014). This was also found in this study both under water deficit and paraquat-induced stress, which indicates that the decrease in the $F_{\mathrm{v}} / F_{\mathrm{m}}$ ratio is a good indicator of photoinhibition damage when plants are submitted to both stressors.

The greater gs reductions in all cultivars, when treated with $+\mathrm{PQ}$, indicate that the herbicide toxic effect induced oxidative stress, causing damage in the sub-stomatal cells and may have contributed to the stomatal closure or rupture in these cultivars. Behaviors like these were also reported in other vegetable species with a great reduction of gs in plants treated with paraquat, e.g., in wheat (Sedigheh et al. 2011) and Conyza bonariensis (Shaaltiel and Gressel 1987). These authors suggested that paraquat caused the closure of the stomata because of damage in the membrane and loss of water from the guard cells, hindering $\mathrm{CO}_{2}$ fixation.

In fact, stomatal closure was the primary cause of the response to water stress in cultivars, particularly SP813250, with lower gs values (Fig. 2b), i.e., greater stomatal sensitivity. Similar findings in sugarcane were also reported by Graça et al. (2010) and Silva et al. (2012), who found greater stomatal closure in cultivars regarded as more sensitive to stress. On the other hand, the smaller gs reduction observed in SP83-2847, when treated with $+\mathrm{D}$, suggest that these cultivars are more effective in stomatal control in water-stressed soils when compared with other cultivars. According to Lawlor and Tezara (2009), under water stress, plants keep their stomata closed as a way to minimize loss of water and maintain foliar turgor, an important feature for drought tolerance.

Under water deficit, the lowest SPAD values were observed in cultivars RB92579 and SP81-3250, with mean values below 40 (Fig. 2c), suggesting that these plants are more sensitive to drought. These results corroborate those found by Jangpromma et al. (2010a), Silva et al. (2012), and Silva et al. (2014), who reported SPAD values below 40 in sugarcane-sensitive cultivars when submitted to drought conditions. According to Silva et al. (2007), SPAD readings below 40 indicate the onset of chlorophyll deficit, which affects the photosynthetic process, a parameter considered as a good indicator of disturbances caused by water stress in sugarcane. But such considerable reduction was not observed when cultivars were treated with paraquat, suggesting that the $24 \mathrm{~h}$ period after application may have been a short time, requiring a longer period to confirm the occurrence of chlorophyll damage in sugarcane leaves.

Regarding the contents of photosynthetic pigments, cultivars IAC91-5155 and SP83-2847 presented lower decreases when treated with +PQ (Fig. 3a-c), suggesting a greater ability to maintain chlorophyll levels under the phototoxicity of paraquat herbicide. According to Altinkut et al. (2001), reduced concentrations of chlorophylls may be associated with photooxidative processes or alteration in the organization of photosystems, so as to act as a mechanism of photoprotection to prevent severe photodestruction of the chloroplast. Chagas et al. (2008) also found a reduction in the total chlorophyll contents in sugarcane and Darkó et al. (2009) found it in maize when treated with paraquat.

It was found in cultivars SP81-3250 and RB92579, a high degradation of chlorophyll under water deficit and treated with +PQ (Fig. 3a-c). Chlorophyll degradation is one of the consequences of stress that may result from photoinhibition and reduced photosynthetic efficiency among other cellular processes (Long et al. 1994; Murchie and Niyogi 2011). According to Sood et al. (2011), paraquat causes oxidative stress in chloroplasts, which may have contributed to the increased production of ROS, resulting in damages of the photosynthetic apparatus such as chlorophyll pigment degradation.

Great reductions in chlorophyll levels were also found in other sugarcane cultivars considered susceptible as a result of water stress (Cha-Um and Kirdmanee 2009; Jangpromma et al. 2010b) and salt stress (Gomathi and Rakkiyapan 2011). Based on this, it can be assumed that, with respect to chlorophyll levels, the sensitivity of the cultivars in this study to drought and paraquat-induced stress indicates that the mechanisms of adaptation are similar to those to oxidative stress, which suggests that this parameter is considered a good indicator of disturbances caused by both stresses in plants.

The unaltered carotenoid levels in cultivars in SP832847 and IAC91-5155 under water stress (Fig. 3d) suggests that these cultivars have a greater protection against photooxidation during the oxidative stress, but the rise of the carotenoid levels in cultivars SP81-3250 and RB92579 treated with paraquat were not sufficient to prevent oxidative damages, as suggested by the high chlorophyll degradation rates and the great reduction of the maximum photochemical efficiency of photosystem II in these cultivars.

Present in chloroplasts, carotenoids have a non-enzymatic antioxidant photoprotective role in photosynthetic 
tissue with the function of dissipating the excess energy of chlorophyll as heat, reducing the chlorophyll excited state. When this does not occur, reactive chlorophyll may react with molecular oxygen, forming singlet oxygen, superoxide anion, hydroxyl radicals, and hydrogen peroxide, which are detrimental to many cell components, especially lipids (Jaleel et al. 2009; Gomathi and Rakkiyapan 2011). Thus, these pigments are important in preventing induction of oxidative damage caused by stress (Wahid 2007).

The increased carotenoids concentration has been suggested as a mechanism of tolerance of sugarcane to oxidative stress, reported in various stress conditions in sugarcane, such as water deficit and salinization (Cha-Um and Kirdmanee 2009; Patade et al. 2011), as well as thermal stress (Wahid 2007). Few studies have reported the phytotoxicity effect of paraquat on the carotenoid levels, but some results were published on wheat leaves (Ekmekci and Terzioglu 2005) and maize leaves (Shahrtash et al. 2011), but nothing was found on sugarcane.

The plants exposure to the PQ herbicide was detrimental to the metabolism for protein production, causing its reduction in all cultivars. According to Sood et al. (2011) and Shahrtash et al. (2011), paraquat in plants induces oxidative stress, contributing to an increased production of ROS, which favors protein denaturation or degradation.

Under paraquat-induced stress, protein reductions in sugarcane cultivars (Chagas et al. 2008), maize (Shahrtash et al. 2011) and inferior Azolla microphylla Kaul (Sood et al. 2011) were also observed. According to these authors, protein denaturation and degradation as well as membrane damages are higher as the exposure time and paraquat dosage increase, which is due to the increased ROS levels induced by oxidative stress. The reduction in the soluble protein concentrations in all cultivars during the period of water stress also suggests that this was probably due to the interruption of protein synthesis (Patade et al. 2011).

Paraquat-induced oxidative stress caused reduction in total soluble carbohydrates for most of the cultivars (Fig. 4a). In the literature, no results addressing responses to paraquat-induced stress in the leaf contents of soluble carbohydrates were found. However, this study suggests that carbohydrate reduction was due to the paraquat toxic effect, causing damage to the chloroplast, such as degradation and destruction of amino molecules in plants.

Under water stress, such responses were inverse, with increased sugar concentrations in cultivars RB92579, SP83-2847, and IAC91-5155 (Fig. 4a), which indicates that the buildup of soluble sugar is probably associated with mechanisms that prevent water loss in plants, such as osmotic adjustment (Hayat et al. 2012). Sales et al. (2012), studying water-stressed sugarcane found that total soluble carbohydrates remained constant in the leaves and greater in the roots. According to these authors, soluble carbohydrates remain in the leaves and roots probably because of the degradation of starch reserves. The increased levels of total soluble carbohydrates were also observed in water- and salt-stressed sugarcane (Patade et al. 2011). These studies suggest that the accumulation of soluble carbohydrates is involved in the osmotic adjustment.

Paraquat-induced oxidative stress contributed to the reduction of proline in all cultivars (Fig. 4b) indicating that this herbicide was involved in biosynthesis inhibition and/ or in proline destruction, an based on this it can be assumed that the PQ concentration of $150 \mu \mathrm{M}$ for $24 \mathrm{~h}$ was highly toxic for proline and should have inhibited the restoration processes, which are linked to proline synthesis in chloroplast.

However, some studies demonstrated that proline is involved in the protective system against oxidative damages induced by paraquat stress (Molinari et al. 2007; Shevyakova et al. 2009; Shahrtash et al. 2011), a fact not found in this research. In a study using sugarcane leaf disks, Molinari et al. (2007) studied oxidative stress mediated by $5 \mu \mathrm{M}$ of paraquat for $24 \mathrm{~h}$, and found in transgenic plants some genes that stimulated the production of proline, and when treated with paraquat, leaves remained green and with higher content of chlorophyll. Such study demonstrated the protective effects of proline against damages caused by paraquat, confirming the hypothesis of its role as ROS antioxidant agent.

The increased accumulation of proline in cultivars under water stress suggests that such amino acid may be involved in the mechanism of osmoregulation and antioxidant defense, contributing to balanced ROS in leaves, as reported in previous studies on water-stressed sugarcane (Molinari et al. 2007; Cia et al. 2012; Hemaprabha et al. 2013). Thus, proline concentrations may be a good biochemical parameter as indicator of water stress, although they were not efficient in signaling paraquat mediated stress due to the great reduction caused by the herbicide in organic solute.

The increased SOD activity in both stress conditions suggests that this enzyme played a signaling role of ROS overproduction, especially superoxide radical $\left(\mathrm{O}_{2}^{--}\right)$, because SOD acts in chloroplasts removing and transforming $\mathrm{O}_{2}^{--}$to $\mathrm{H}_{2} \mathrm{O}_{2}$, and this is detoxified by another set of enzymes, CAT, GPX, and APX (Mittler 2002; Sharma et al. 2012).

The stress caused by paraquat induced the increase of the SOD enzyme in all cultivars (Fig. 4d), indicating that this herbicide is a powerful inducer of oxidative stress. About paraquat-induced stress, various studies report that the herbicide toxicity is mediated by the significantly increased SOD activation to balance the antioxidant system, as previously observed in sugarcane (Chagas et al. 
2008), maize (Darkó et al. 2009), rice (Guo et al. 2007) and wheat (Shevyakova et al. 2009).

In 15 days under water stress, all cultivars also showed an increased SOD activity, a signal of oxidative stress condition in the plants. According to Cia et al. (2012), an unaltered or increased SOD activity in sugarcane under drought may be considered an evidence of tolerance, while a reduced activity may indicate sensitivity to drought. The association between the levels of SOD activity with sugarcane drought tolerance has been previously observed. For example, Jangpromma et al. (2010b) found a higher increase in SOD activity in drought-tolerant cultivars, and Gomathi and Rakkiyapan (2011), when studying sugarcane under salt-induced stress, found that the SOD activity tended to increase in the tolerant cultivar.

The increased activity of the CAT enzyme in cultivars treated with $+\mathrm{PQ}$ (Fig. 4e) suggests that the plants used this enzyme as a defense mechanism against the oxidative damages provoked by the herbicide. Various studies consider the increased CAT activity as an important antioxidant defense system against paraquat-induced oxidative stress, such as in pea leaves (Iturbe-Ormaetxe 1998), wheat (Ekmekci and Terzioglu 2005), and maize (Shahrtash et al. 2011). The high concentrations of the CAT enzyme are important to reduce $\mathrm{H}_{2} \mathrm{O}_{2}$ concentrations, so this enzyme plays a key role in the plants' final adaptation and survival during stress periods (Asada 1999; Gill and Tuteja 2010).

The reduction of the catalase activity in cultivars RB92579 and SP81-3250 under water deficit suggests more sensitivity of these plants when exposed to drought stress. The CAT is an enzyme considered very sensitive to abiotic stress, which may induce CAT inactivation in sugarcane (Srivastava et al. 2012), and so it is a good enzyme to signal drought stress in this culture. The maintenance of the CAT activity in cultivar IAC91-5155 and the increased CAT activity in SP83-2847 may be an indicative feature of these cultivars to respond to oxidative stress and perceived as having better leaf ability to decompose $\mathrm{H}_{2} \mathrm{O}_{2}$.

The CAT enzyme is the second prevention system of oxidative stress. This enzyme acts in the dismutation of hydrogen peroxide $\left(\mathrm{H}_{2} \mathrm{O}_{2}\right)$ produced by $\mathrm{SOD}$, the first prevention system, with oxygen and water (Mittler 2002; Sharma et al. 2012). Cia et al. (2012) found that the sensitive cultivar showed a decline in the CAT activity as water deficit increased. Srivastava et al. (2012), in sugarcane under thermal stress, found that high temperatures reduced CAT activity in tolerant cultivars.

In APX activity, it was observed an increased production of this enzyme in all cultivars under drought or paraquat-induced stress (Fig. 4f). This indicates the key role of APX in providing cultivars with protection against the potential increase of de $\mathrm{H}_{2} \mathrm{O}_{2}$ produced by drought and toxicity of the paraquat herbicide, which confirms that the increased APX activity may be closely related to tolerance to these stressors, due to its effective ability to eliminate $\mathrm{H}_{2} \mathrm{O}_{2}$ (Noctor and Foyer 1998; Sharma et al. 2012).

Other studies reported that the increased activity of the antioxidant enzymes SOD, CAT, and APX had a detoxification action, contributing to the decrease in lipid peroxidation, thus playing a key role in the mechanism of tolerance to PQinduced oxidative stress in various cultures (Ekmekci and Terzioglu 2005; Sood et al. 2011; Yoon et al. 2011). Inverse responses were found by Chagas et al. (2008), who studied paraquat-induced stress in sugarcane and noticed a high APX reduction, suggesting that the oxidative damages in sugarcane leaves were associated with excess $\mathrm{H}_{2} \mathrm{O}_{2}$, probably in chloroplasts, caused by an unbalanced activity of SOD and APX, because while SOD increased, APX decreased.

The ability of cultivars IAC91-5155 and SP83-2847 to produce higher dry matter of shoots, roots and total under water stress can confer greater tolerance to drought conditions. According to Aguilera et al. (1999), the degree of limitation promoted by environmental stress upon the biomass varies among genotypes of the same species. Thus, the ability to maintain key physiological processes under water scarcity is a potential indicative of also maintaining the productivity.

\section{Conclusion}

The results discussed here are related to oxidative stress induced by paraquat and water deficit, mediated by physiological attributes and biochemical damages, aspects not available today in the literature on sugarcane crop. Thus, cultivars were exposed to two kinds of stress of economic interest to sustainable agriculture. Due to minor damage caused by drought in the physiology and biochemistry of cultivars SP83-2847 and IAC91-5155, these cultivars exhibited a greater potential for tolerating and acclimating to drought. Consequently, oxidative stress can be largely avoided in the chloroplasts of these cultivars by maintaining a balance of antioxidant enzyme activity, photosynthetic efficiency, stomatal control and water status. The lower toxicity degrees of paraquat in cultivars SP83-2847 and IAC91-5155 are related to the increase or at least the maintenance of the activity of SOD, CAT, and APX enzymes, which must have contributed to the reduction of oxidative stress, as evidenced by the lower reductions of $F_{\mathrm{v}} / F_{\mathrm{m}}$ and chlorophylls. Therefore, antioxidant enzymes may be considered potential defense mechanisms for oxidative stress in sugarcane. The variables $F_{\mathrm{v}} / F_{\mathrm{m}}, \Psi_{\mathrm{w}}$, SPAD index, photosynthetic pigments, and dry mass are potentially reliable physiological indicators for selecting sugarcane cultivars tolerant to water deficit, and $F_{\mathrm{v}} / F_{\mathrm{m}}$ and photosynthetic pigments to oxidative stress induced by 
paraquat. We recommend these measures for identifying tolerant genotypes in genetic breeding programs, thus providing ideal material for molecular studies on drought.

Authors contribution statement Claudiana M. dos Santos set up and carried out the experiments, analyzed and interpreted the data, and prepared the manuscript. Marcelo de A. Silva planned and wrote the proposal, designed and supervised the experiments, interpreted the data, and was responsible for the manuscript preparation.

Acknowledgments The authors thank the National Council for Scientific and Technological Development (CNPq, Brazil) for supporting this research (Proc. 473980/2009-6) and for "Productivity in Research" Fellowship (Proc. 311255/2012-4) to the second author.

\section{References}

Aguilera C, Stirling CM, Long SP (1999) Genotypic variation within Zea mays for susceptibility to and rate of recovery from chillinduced photoinhibition of photosynthesis. Physiol Plant 106:429-436

Altinkut A, Kazan K, Ipekci Z, Gozukirmizi N (2001) Tolerance to paraquat is correlated with the traits associated with water stress tolerance in segregating F2 populations of barley and wheat. Euphytica 121:281-286

Apel K, Hirt H (2004) Reactive oxygen species: metabolism, oxidative stress, and signal transduction. Annu Rev Plant Biol 55:373-399

Asada K (1999) The water-water cycle in chloroplasts: scavenging of active oxygens and dissipation of excess photons. Annu Rev Plant Phys Mol Biol 50:601-639

Bates LS, Waldren RP, Teare ID (1973) Rapid determination of free proline for water stress studies. Plant Soil 39:205-207

Beauchamp CO, Fridovich I (1973) Isoenzymes of superoxide dismutase from wheat germ. Biochim Biophys Acta 317:50-64

Bradford MM (1976) A rapid and sensitive method for the quantitation of microgram quantities of protein utilizing the principle of protein-dye binding. Anal Biochem 72:248-254

Carvalho MHC (2008) Drought stress and reactive oxygen species: production, scavenging and signaling. Plant Signal Behav 3:156-165

Chagas RM, Silveira JAG, Ribeiro RV, Vitorello VA, Carrera H (2008) Phytochemical damage and comparative performance of superoxide dismutase and ascorbate peroxidase in sugarcane leaves exposed to paraquat-induced oxidative stress. Pestic Biochem Phys 90:181-188

Chapola RG, dos Santos EGD, Rosa JRBE, Fernandes AR Jr, Al Bassinello, Vieira MAS, Hoffmann HP (2009) Censo varietal de cana-de-açúcar do Estado de São Paulo em 2008. STAB Açúcar, Álcool e Subprodutos 27:36-39

Cha-um S, Kirdmanee C (2009) Proline accumulation, photosynthetic abilities and growth characters of sugarcane (Saccharum officinarum L.) plantlets in response to iso-osmotic salt and waterdeficit stress. Agr Sci China 8:51-58

Cia MC, Guimarães ACR, Medici LO, Chabregas SM, Azevedo RA (2012) Antioxidant responses to water deficit by drought-tolerant and -sensitive sugarcane varieties. Ann Appl Biol 161:313-324

Darkó E, Ambrus H, Fodor J, Király Z, Barnabá B (2009) Enhanced tolerance to oxidative stress with elevated antioxidant capacity in doubled haploid maize derived from microspores exposed to paraquat. Crop Sci 49:628-636
Dubois M, Gilles KA, Hamilton JK, Rebers PA, Smith F (1956) Colorimetric method for determination of sugars and related substances. Anal Chem 28:350-356

Ekmekci Y, Terzioglu S (2005) Effects of oxidative stress induced by paraquat on wild and cultivated wheats. Pestic Biochem Phys 83:69-81

Gill SS, Tuteja N (2010) Reactive oxygen species and antioxidant machinery in abiotic stress tolerance in crop plants. Plant Physiol Biochem 48:909-930

Gomathi R, Rakkiyapan P (2011) Comparative lipid peroxida-tion, leaf membrane ther most ability, and antioxidant systemin four sugarcane genotypes differing in salt tolerance. Inter J Plant Physiol Biochem 3:67-74

Gomathi R, Manohari G, Rakkiyappan P (2012) Antioxidant enzymes on cell membrane integrity of sugarcane varieties differing in flooding tolerance. Sugar Tech 14:261-265

Gorai M, Ennajeh M, Khemira H, Neffati M (2010) Combined effect of $\mathrm{NaCl}$-salinity and hypoxia on growth, photosynthesis, waterrelations and solute accumulation in Phragmites australis plants. Flora 205:462-470

Graça JP, Farias JRB, Oliveira MCN, Hoffmann-Campo CB, Zingaretti SM (2010) Physiological parameters in sugarcane cultivars submitted to water deficit. Braz J Plant Physiol 22:189-197

Guo Z, Huang M, Lu S, Yaqing Z, Zhong Q (2007) Differential response to paraquat induced oxidative stress in two rice cultivars on antioxidants and chlorophyll $a$ fluorescence. Acta Physiol Plant 29:39-46

Havir EA, Mchale NA (1987) Biochemical and developmental characterization of multiple forms of catalase in tobacco leaves. Plant Physiol 84:450-455

Hayat S, Hayat Q, Alyemeni MN, Wani AS, Pichtel J, Ahmad A (2012) Role of proline under changing environments: a review. Plant Signal Behav 7:1456-1466

Hemaprabha G, Nagarajan R, Alarmelu S (2013) Evaluation of drought tolerance potential of elite genotypes and progenies of sugarcane (Saccharum sp. hybrids). Sugar Tech 15:9-16

Iturbe-Ormaetxe I et al (1998) Oxidative damage in pea plants exposed to water deficit or paraquat. Plant Physiol 116:173-181

Jaleel CA, Manivannan P, Wahid A, Farooq M, Al-Juburi HJ, Somasundaram R, Panneerselvam R (2009) Drought stress in plants: a review on morphological characteristics and pigments composition. Int J Agric Biol 11:100-105

Jangpromma N, Songsri P, Thammasirirak S, Jaisil P (2010a) Rapid assessment of chlorophyll content in sugarcane using a spad chlorophyll meter across different water stress conditions. Asian J Plant Sci 9:368-374

Jangpromma N, Kitthaisong S, Lomthaisong K, Daduang S, Jaisil P, Thammasirirak S (2010b) Proteomics analysis of drought stressresponsive proteins as biomarker for drought-tolerant sugarcane cultivars. Am J Biochem Biotech 2:89-102

Kar ME, Mishra D (1976) Catalase, peroxidase and polyphenoloxidase actives during rice leaf senescence. Plant Physiol 57:315-319

Lawlor DW, Tezara W (2009) Causes of decreased photosynthetic rate and metabolic capacity in water-deficient leaf cells: a critical evaluation of mechanisms and integration of processes. Ann Bot 103:561-579

Lichtenthaler HK (1987) Chlorophylls and carotenoids: pigments of photosynthetic biomembranes. Method Enzymol 148:350-382

Lin S-H, Liu Z-J, Xu P-L, Fang Y-Y, Ba J-G (2011) Paraquat pretreatment increases activities of antioxidant enzymes and reduces lipid peroxidation in salt-stressed cucumber leaves. Acta Physiol Plant 33:295-304 
Long SP, Humphries S, Falkowski PG (1994) Photoinhibition of photosynthesis in nature. Annu Rev Plant Phys Mol Biol 45:633-662

Maxwell K, Johnson GN (2000) Chlorophyll fluorescence: a pratical guide. J Exp Bot 51:659-668

Mittler R (2002) Oxidative stress, antioxidants and stress tolerance. J Trends Plant Sci 7:405-410

Molinari HBC, Marur CJ, Daros E, Campos MKF, Carvalho JFRP, Bespalhok Filho JC, Pereira LFP, Vieira LGE (2007) Evaluation of the stress-inducible production of proline in transgenic sugarcane (Saccharum spp.): osmotic adjustment, chlorophyll fluorescence and oxidative stress. Physiol Plant 130:218-229

Murchie EH, Niyogi KK (2011) Manipulation of photoprotection to improve plant photosynthesis. Plant Physiol 155:86-92

Nakano Y, Asada K (1981) Hydrogen peroxide is scavenged by ascorbate-sepecific peroxidase in spinach choloroplasts. Plant Cell Physiol 22:867-880

Noctor G, Foyer CH (1998) Ascorbate and Glutathione: keeping active oxygen under control. Annu Rev Plant Phys Mol Biol 49:249-279

Patade VP, Bhargava S, Suprasanna P (2011) Salt and drought tolerance of sugarcane under iso-osmotic salt and water stress: growth, osmolytes accumulation, and antioxidant defense. J Plant Interact 6:275-282

Sales CRG, Machado DFSP, Machado RS, Dovis VL, Lagôa AMM (2012) Trocas gasosas e balanço de carboidratos em plantas de cana-de-açúcar sob condições de estresses radiculares. Bragantia 71:319-327

Sedigheh HG, Mortazavian M, Norouzian D, Atyabi M, Akbarzadeh A, Hasanpoor K, Ghorbani M (2011) Oxidative stress and leaf senescence. BMC Res Notes 4:1-9

Shaaltiel Y, Gressel J (1987) Kinetic analysis of resistance to paraquat in Conyza: evidence that paraquat transiently inhibits leaf chloroplast reactions in resistant plants. Plant Physiol $85: 869-871$

Shahrtash M, Mohsenzadeh S, Mohabatkar H (2011) Salicylic acid alleviates paraquat oxidative damage in maize seedling. Asian $\mathrm{J}$ Exp Biol Sci 2:377-382

Sharma P, Jha AB, Dubey RS, Pessarakli M (2012) Reactive oxygen species, oxidative damage, and antioxidative defense mechanism in plants under stressful conditions. J Bot. doi:10.1155/2012/ 217037

Shevyakova NI, Bakulina EA, Kuznetsov VIV (2009) Proline antioxidant role in the common ice plant subjected to salinity and paraquat treatment inducing oxidative stress. Russian J Plant Physiol 56:736-742

Silva MA, Jifon JL, Da Silva JAG, Sharma V (2007) Use of physiological parameters as fast tools to screen for drought tolerance in sugarcane. Braz J Plant Physiol 19:193-201

Silva MA, Jifon JL, Sharma V, Silva JAG, Caputo MC, Damaj MB, Guimarães ER, Ferro MIT (2011) Use of physiological parameters in screening drought tolerance in sugarcane genotypes. Sugar Tech 13:191-197

Silva PP, Soares L, Costa JG, Viana LS, Andrade JCF, Gonçaves ER, Santos JM, Barbosa GVSB, Nascimento VX, Todaro AR, Riffel A, Grossi-de-Sa MF, Barbosa MHP, Sant'ana AEG, Ramalho Neto CE (2012) Path analysis for selection of drought tolerant sugarcane genotypes through physiological components. Ind Crop Prod 37:11-19

Silva MA, Jifon JL, Santos CM, Jadoski CJ, Silva JAG (2013) Photosynthetic capacity and water use efficiency in sugarcane genotypes subject to water deficit during early growth phase. Braz Arch Biol Technol 56:735-748

Silva MA, John JL, da Silva JAG, Santos CM, Sharma V (2014) Relationships between physiological traits and productivity of sugarcane in response to water deficit. J Agr Sci 152:104-118

Sood A, Pabbib S, Uniyala PL (2011) Effects of paraquat on lipid peroxidation and antioxidant enzymes in aquatic fern Azolla microphylla. Russian J Plant Physiol 58:667-673

Srivastava S, Pathak AD, Gupta PD, Shrivastava AK, Srivastava AK (2012) Hydrogen peroxide scavenging enzymes impart tolerance to high temperature induced oxidative stress in sugarcane. J Environ Biol 33:657-661

Taiz L, Zeiger E (2010) Plant Physiology, 5th edn. Sinauer Associates Inc, Sunderland, $\mathrm{p} 782 \mathrm{p}$

Waclawovsky AJ, Sato PM, Lembke CG, Moore PH, Souza GM (2010) Sugarcane for bioenergy production: an assessment of yield and regulation of sucrose content. Plant Biotech J 8:1-14

Wahid A (2007) Physiological implications of metabolite biosynthesis for net assimilation and heat-stress tolerance of sugarcane (Saccharum officinarum) sprouts. J Plant Res 120:219-228

Yoon JY, Shin JS, Shin DY, Hyun KH, Burgos NR, Lee S, In Kuk Y (2011) Tolerance to paraquat-mediated oxidative and environmental stresses in squash (Cucurbita spp.) leaves of various ages. Pest Biochem Phys 99:65-76 